\title{
Expression of Manganese Superoxide Dismutase in Ovine Kidney Cortex during Development
}

\author{
G. M. R. CARBONE, D. K. ST. CLAIR, Y. ANNE XU, AND J. C. ROSE \\ Department of Physiology and Pharmacology, Perinatal Research Laboratories, Bowman Gray School of \\ Medicine of Wake Forest University, Winston-Salem. North Carolina 27157 [G.M.R.C., J.C.R.], and Graduate \\ Center for Toxicology, University of Kentucky, Lexington, Kentucky 40506-0054 [D.K.St.C., Y.A.X.]
}

\begin{abstract}
Manganese superoxide dismutase (MnSOD) is one of the main antioxidant enzymes in mammalian tissue. Previous studies have shown that the activity of MnSOD increases in the rat kidney during development. To define further the developmental change in MnSOD activity and better understand some of the steps involved in the control of MnSOD expression during kidney development, we measured MnSOD messenger RNA and enzyme activity in the ovine kidney cortex during fetal life, in the newborn period, and in adults. MnSOD mRNA and enzyme activity were detected at 0.65 gestation. Hybridization of the Northern blot with a human MnSOD cDNA probe showed evidence of two transcripts of 4.0 and 1.5 $k b$, respectively. There was a significant increase with age of MnSOD activity and MnSOD mRNA $(p<0.0001)$. The abundance of each MnSOD transcript significantly increased with age $(p<0.001)$. In the fetuses, both transcripts increase in parallel; in newborns and adults the 1.5$\mathrm{kb}$ increase was significantly greater than the $4.0-\mathrm{kb}$ increase. Enzyme activity and mRNA were strongly correlated $(r=0.89, p<0.0001)$. These data indicate that the expression of MnSOD is developmentally regulated in the ovine kidney cortex. This increase seems to be dependent largely on pretranslational events. (Pediatr Res 35: 41-44, 1994)
\end{abstract}

\section{Abbreviations}

SOD, superoxide dismutase

MnSOD, manganese superoxide dismutase

CuZnSOD, copper and zinc superoxide dismutase

NBT, nitroblue tetrazolium

$G$, gestation

Superoxide dismutases are enzymes that catalyze the dismutation of superoxide radicals into oxygen and hydrogen peroxide. In eukaryotic cells two forms of SOD are found, one containing copper and zinc (CuZnSOD) in the cytosol and one containing manganese (MnSOD) in the mitochondrial matrix. Inefficient detoxification of superoxide radicals has been associated with the etiology of various diseases in adults and premature infants (1-3). Studies in several experimental animal models, including sheep, have shown that antiox 'ant enzymes are weakly expressed in fetal lung until late in gestation. It has been suggested that infants born prematurely would be at increased risk for oxidative stress because of the reduced levels of lung antioxidant activity (4-6).

Received June 8, 1993; accepted September 9, 1993.

Correspondence: Giuseppina Carbone, M.D., Department of Physiology/Pharmacology, Bowman Gray School of Medicine, Winston-Salem, NC 27157.

Supported by National Institutes of Health Grants HD17644 and CA49797.
Recent data indicate that the activity of antioxidant enzymes is developmentally regulated in the kidney as it is in the lung. MnSOD activity has been shown to increase in guinea pig and rat kidney from fetal to the adult period $(2,7)$. In addition, MnSOD has been also detected by immunohistochemistry in kidney cortex and medulla in the Syrian hamster and the staining increases progressively during development (8).

Therefore, to understand better the mechanisms of MnSOD expression in the developing kidney, we measured MnSOD activity and mRNA levels in ovine kidney cortex in early gestation $(0.65 \mathrm{G})$ and late gestation fetuses $(0.96 \mathrm{G})$, newborn lambs and adult sheep. We hypothesized that parallel increases in mRNA and enzyme activity would occur as maturation progressed.

\section{MATERIALS AND METHODS}

Animals. Ewes with known single insemination dates in which pregnancy was confirmed at $50 \mathrm{~d}$ of gestation by ultrasound, and nonpregnant adult animals, were obtained from a local supplier. Newborn lambs were obtained from pregnant ewes brought to the vivarium at term and allowed to deliver naturally. Pregnant ewes were anesthetized with ketamine $10 \mathrm{mg} / \mathrm{kg}$. The fetuses were delivered through an abdominal hysterotomy, given a lethal dose of pentobarbital and the kidneys were removed. Samples of kidney cortex were obtained from 2 female and 4 male fetuses at 92-94 days of gestation (early gestation, EG) and from 3 female and 3 male fetuses at 138-142 days of gestation (late gestation, LG). Tissues were collected similarly from 2 female and 3 male newborn lambs (0.4-2 days old) and 4 female nonpregnant sheep. Slices of kidney cortex were obtained by radial slicing, including inner and outer cortex, immediately frozen in liquid nitrogen and stored at $-80^{\circ} \mathrm{C}$ until processed. All procedures were approved by our Institutional Animal Care and Use Committee.

MnSOD activity assay. The SOD activity was determined by the NBT method as previously described (9). Briefly, tissue was homogenized on ice $(100 \mathrm{~g} / \mathrm{L})$ in $50 \mathrm{mM}$ phosphate buffer $(\mathrm{pH}$ 7.8) with a tissue homogenizer (Tekmar Co., Cincinnati, $\mathrm{OH}$ ) by three bursts of $30 \mathrm{sec}$ each. The homogenate was then sonicated on ice with a sonic dismembrator (Fisher Scientific, Pittsburgh, PA; model 550) for three cycles of $30 \mathrm{sec}$ each. Protein content was determined by the method of Bradford (10). Tissue samples containing from 0 to $500 \mu \mathrm{g}$ of protein were incubated with $10^{-4}$ $M$ xanthine, $5 \times 10^{-5} \mathrm{M}$ NBT, 1 unit of catalase, and $1 \mathrm{mM}$ diethylenetriaminepentoacetic acid. As soon as xanthine oxidase $\left(10^{-3}\right.$ units) was added to the mixture, the rate of reaction was monitored by following the changes in absorbance of the mixture with a spectrophotometer at $560 \mathrm{~nm}$ (Shimadzu UV-Vis spectrophotometer, Shimadzu Scientific Instruments, Columbia, MD). Endogenous xanthine oxidase inhibitory activity was measured in a representative sample from each tissue by following the conversion of xanthine to uric acid at $290 \mathrm{~nm}$. The sensitivity of 
this assay was such that 1 unit of SOD activity equalled $15 \pm 3$ ng of pure bovine liver SOD. To specifically measure the activity of $\mathrm{MnSOD}, 5 \times 10^{-3} \mathrm{M}$ of sodium cyanide $(\mathrm{NaCn})$ was added to the incubation mixture for $30 \mathrm{~min}$ to inhibit CuZnSOD. In the tissues studied no appreciable reduction of NBT by endogenous reductase occurred and the activity of xanthine oxidase remained unchanged during the course of the assay.

Total RNA extraction. The total RNA was extracted from fetal, newborn, and adult kidneys using a modified acid-guanidinium procedure (11). Tissue slices were homogenized $(100 \mathrm{~g} /$ $\mathrm{L}$ ) in RNA extraction buffer (4 M guanidinium thiocyanate, 25 mM sodium citrate, $\mathrm{pH} 7.0,0.5 \%$ sarcosyl, and $0.1 \mathrm{M} \beta$-mercaptoethanol) with polytron homogenizer (Brinkmann Instruments Co., Westbury, NY) at setting 6 for $30 \mathrm{~s}$. After homogenization, $50 \mu \mathrm{L}$ of $2 \mathrm{M}$ sodium acetate, $\mathrm{pH} 4.0,500 \mu \mathrm{L} \mathrm{H} \mathrm{H}_{2} \mathrm{O}$-saturated phenol, and $100 \mu \mathrm{L}$ of chloroform-isoamyl alcohol (49:1) were added. After this the samples were centrifuged for $3 \mathrm{~min}$ at $14000 \times g$ and 1 volume of ice-cold isopropyl alcohol was added to the aqueous phase. After incubation at $-80^{\circ} \mathrm{C}$ for $15 \mathrm{~min}$, samples were centrifuged for $10 \mathrm{~min}$. The resulting pellets were dissolved in $500 \mu \mathrm{L}$ of RNA extraction buffer, reprecipitated with the same volume of isopropyl alcohol for $15 \mathrm{~min}$ at $-80^{\circ} \mathrm{C}$, and centrifuged for $10 \mathrm{~min}$. The pellets were then washed twice with cold $75 \%$ ethanol, dried, and resuspended in water that has been treated with diethyl pyrocarbonate. The RNA concentration was determined by absorbance at $260 \mathrm{~nm}$.

Northern blot analysis. Total RNA $(20 \mu \mathrm{g})$ from each animal was separated by electrophoresis through formaldehyde-agarose (1.2\%) gels in $10 \mathrm{mM} 3-\mathrm{N}$-morpholine propanesulfonic acid, 1 mM EDTA, $5 \mathrm{mM}$ sodium acetate, and transferred to nylon membrane (Zeta-probe, Bio-Rad) with $20 \times$ SSC. An RNA ladder (0.25-9.5 kb, Bethesda Research Laboratories) was electrophoresed with the samples, stained with ethidium bromide, and photographed for use as a size marker. The nylon membrane was irradiated with ultraviolet light for $90 \mathrm{~s}$ to link the nucleic acids to the membrane irreversibly. The membrane was prehybridized for $4 \mathrm{~h}$ at $65^{\circ} \mathrm{C}$ with $0.5 \mathrm{M}$ sodium phosphate buffer (pH 7) containing 7\% SDS, $1 \mathrm{mM}$ EDTA, denatured salmon sperm DNA $(100 \mathrm{mg} / \mathrm{L})$, and tRNA $(10 \mathrm{mg} / \mathrm{L})$ and then hybridized with the same buffer with the addition of $2 \times 10^{6} \mathrm{cpm} / \mathrm{mL}$ ${ }^{32} \mathrm{P}$ MnSOD cDNA probe. After overnight hybridization, the filter was washed at $65^{\circ} \mathrm{C}$ five times for $10 \mathrm{~min}$ each in a buffer containing $0.1 \mathrm{M}$ EDTA, $1 \%$ SDS, and $40 \mathrm{mM} \mathrm{NaH}{ }_{2} \mathrm{PO}_{4}, \mathrm{pH}$ 6.8 (12). After autoradiography, the MnSOD probe was stripped and the filter was rehybridized with the ${ }^{32} \mathrm{P} \beta$-actin probe $(4 \times$ $10^{6} \mathrm{cpm} / \mathrm{mL}$ ) for control.

Probe preparation. The isolation of full-length cDNA for human MnSOD has been described previously (13). The cDNA probe was labelled with the random priming procedure of Feinberg and Vogelstein (14).

A 770-bp cDNA from chicken $\beta$-actin was obtained from Oncor, Inc., and labeled with the random priming method (14).

Data analysis. After autoradiography the intensity of the bands on all Northern blot autoradiograms was measured by optical densitometry recorded on a laser densitometer. Two measurements of signal intensity at different exposure times were obtained for each sample. To correct for any variation in RNA blotted on the nylon, the densitometric signals obtained from the $\beta$-actin were quantified and results from the MnSOD signal were expressed relative to the $\beta$-actin signal. In previous experiments we demonstrated that $\beta$-actin does not change significantly in the ovine kidney cortex during development and in the adult (15). Duplicate samples of total RNA from each animal were analyzed for MnSOD and $\beta$-actin results were expressed as the average of the two measurements. Data were analyzed by analysis of variance after logarithmic transformation. Differences among groups were evaluated with Newman-Keuls test. A significance level of 0.05 was used to reject the null hypothesis in all cases. MnSOD activity in the kidney cortex was measured from each animal and expressed as units per milligram of total protein.
Data were analyzed by analysis of variance as described for the mRNA. Regression analysis was carried out to determine whether there was a relationship between MnSOD mRNA and enzyme activity.

\section{RESULTS}

The activity of MnSOD was detected in the ovine kidney cortex by $90 \mathrm{~d}$ of gestation $(0.65 \mathrm{G})$. Figure 1 shows the MnSOD activity in the ovine kidney cortex from the animals at each gestational age. There was a significant increase in MnSOD activity from early fetal life to the adult period $(F=29.5, p<$ $0.0001)$. The values of MnSOD activity were lowest in early gestation fetuses $(30 \pm 2.3$ units $/ \mathrm{mg}$ ) and increased similarly in the late gestation fetuses $(42.3 \pm 0.22$ units $/ \mathrm{mg})$ and newborn lambs $(47.5 \pm 4.8$ units $/ \mathrm{mg})(p<0.005)$. Levels in the adult were higher than those observed in fetuses and newborn $(99.5 \pm$ 18.5 units $/ \mathrm{mg})(p<0.0001)$.

To evaluate whether the increase in MnSOD activity was associated with an increase in MnSOD mRNA, the level of MnSOD mRNA was measured in the ovine kidney cortex in the same group of animals. Northern analysis showed the presence of two transcripts of 4.0 and $1.5 \mathrm{~kb}$ in the ovine kidney cortex after hybridization with a human MnSOD cDNA (Fig. 2).

Relative amounts of MnSOD mRNA were quantitated by the Northern blot technique. Figure 3 shows the relative levels of MnSOD mRNA $(1.5+4.0 \mathrm{~kb} / \beta$-actin $)$ observed in each group. MnSOD mRNA levels significantly increased with age $(F=20.2$, $p<0.0001)$. MnSOD mRNA levels were lowest in early gestation fetuses $(0.36 \pm 0.118)$, increased 2 -fold in the late gestation fetuses $(0.635 \pm 0.02)(p<0.05), 3$-fold in the newborn lambs $(1.173 \pm 0.306)(p<0.01)$, and 7 -fold in the adult $(2.52 \pm 1.13)$ $(p<0.001)$. No significant changes in $\beta$-actin were observed in the ovine kidney cortex from the same groups of animals.

To determine whether there was a relationship between MnSOD mRNA and enzyme activity, regression analysis was performed. Figure 4 shows the correlation between $\mathrm{mRNA}$ and enzyme activity. Levels of MnSOD mRNA $(1.5+4.0 \mathrm{~kb})$ and enzyme activity were strongly correlated $(r=0.9, p<0.0001)$. To determine whether the increase in MnSOD was due to a parallel increase of both transcripts, we have quantitated each transcript separately in each animal. Relative levels of the 1.5 and $4.0 \mathrm{~kb}$ transcripts are represented in Figure 5. Both transcripts increase with age $(p<0.001)$. During fetal life the two transcripts increase in parallel and the ratios between 1.5 and 4.0 $\mathrm{kb}$ transcripts did not change (1.5/4.0 kb was $1.1 \pm 0.12$ and 1.1 \pm 0.17 at $0.65 \mathrm{G}$ and $0.95 \mathrm{G}$, respectively). In the newborn and adult sheep, the increase in the 1.5-kb mRNA was greater than the 4-kb mRNA increase, thus the $1.5 / 4.0 \mathrm{~kb}$ ratios were higher

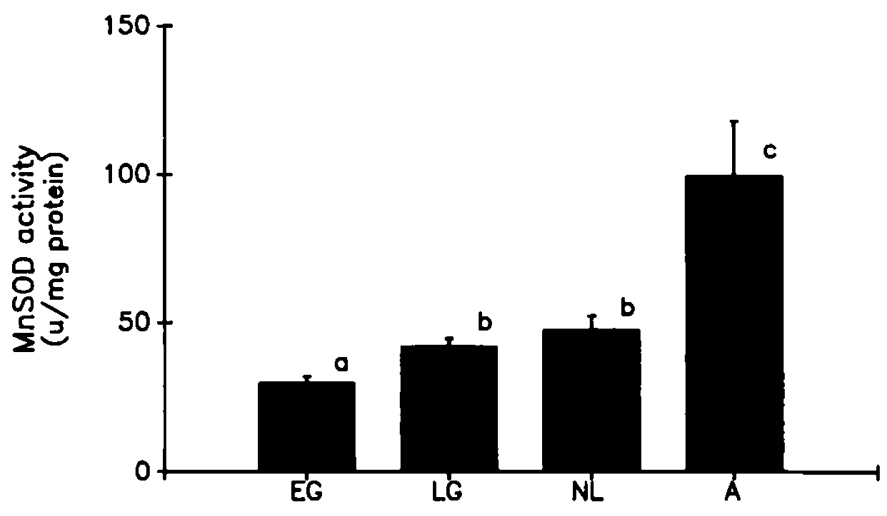

Fig. 1. MnSOD activity (units per milligram of protein). Values represent mean $\pm S E$ of levels in early gestation $(E G)$ fetuses $(n=4)$, late gestation $(L G)$ fetuses $(n=6)$, newborn lambs $(N L)(n=5)$, and adult sheep $(A)(n=4)$. Bars identified by different letters are significantly different. 


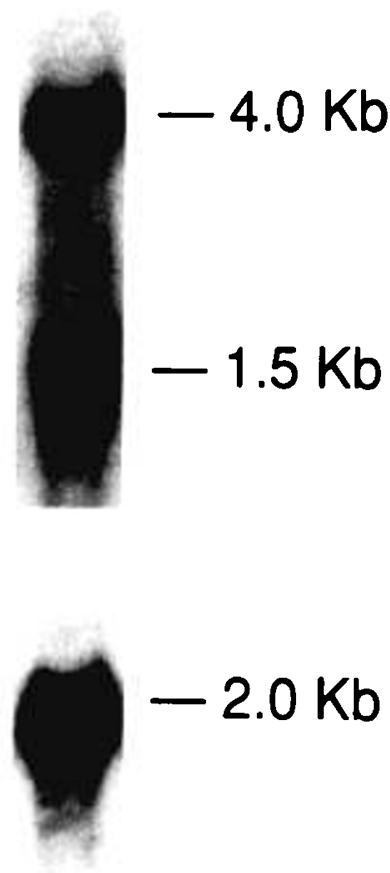

Fig. 2. Upper panel: Northern blot analysis of total RNA from ovine kidney cortex. The lane contained $20 \mu \mathrm{g}$ of total RNA from a late gestation $(L G)$ fetus. Hybridization with a human MnSOD cDNA probe shows evidence of two transcripts of 4.0 and $1.5 \mathrm{~kb}$, respectively (upper panel). The same filter was washed and rehybridized with a $\beta$-actin cDNA probe $(2.0 \mathrm{~kb})$ (lower panel).

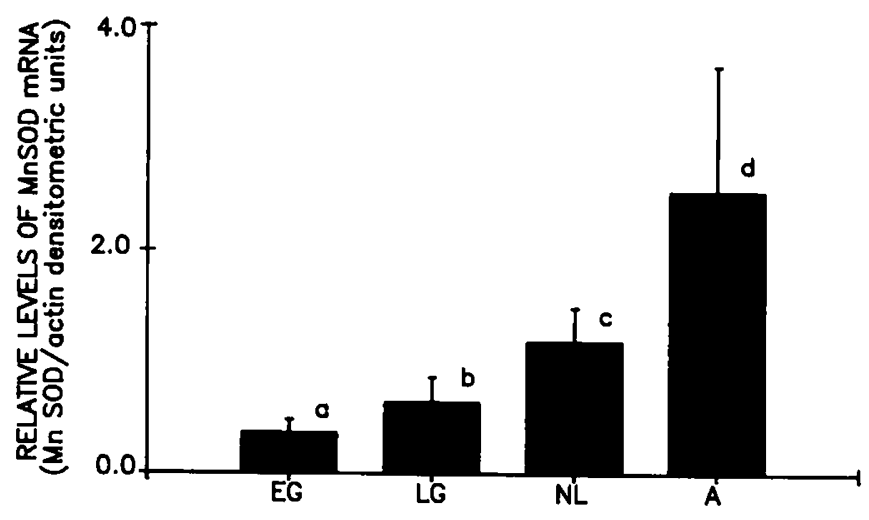

Fig. 3. Relative levels of MnSOD mRNA evaluated by Northern blot technique and densitometric analysis of the autoradiograms. Values represent mean $\pm S E$ of the ratio of $\operatorname{MnSOD}(1.5 \pm 4.0 \mathrm{~kb})$ to $\beta$-actin densitometric units from early gestation $(E G)$ fetuses $(n=6)$, late gestation $(L G)$ fetuses $(n=6)$, newborn lambs $(N L)(n=5)$, and adult sheep $(A)(n=3)$. Different letters above the bars indicate that values are significantly different $(a<b<c<d)$.

than those observed in the fetuses $(1.9 \pm 0.2$ and $1.9 \pm 0.5, p<$ $0.005)$. Enzyme activity correlated well with each single transcript ( $r=0.9, p<0.0001$ for both transcripts).

\section{DISCUSSION}

The antioxidant system may play an important role for the fetus during the perinatal transition to an oxygen rich environment. MnSOD represents the primary antioxidant enzyme in the mitochondria (16).

This study is the first report of the pattern of expression of MnSOD gene (mRNA level and enzyme activity) in the ovine kidney cortex during development. Our results demonstrate that MnSOD gene is expressed in the kidney cortex by 0.65 gestation and that levels progressively increase during development. The

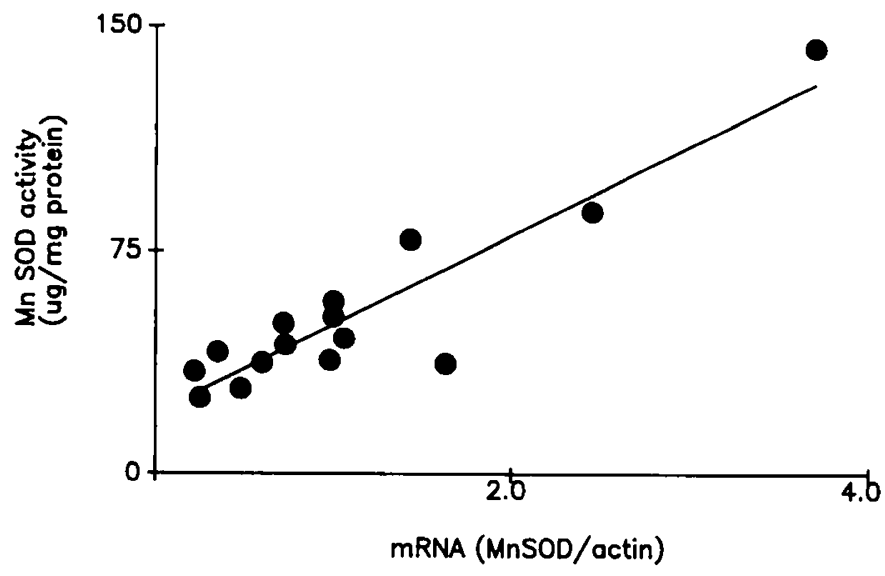

Fig. 4. Correlation between MnSOD mRNA $(1.5+4.0 \mathrm{~kb})$ and MnSOD activity in 18 animals $(r=0.89, p<0.0001)$.

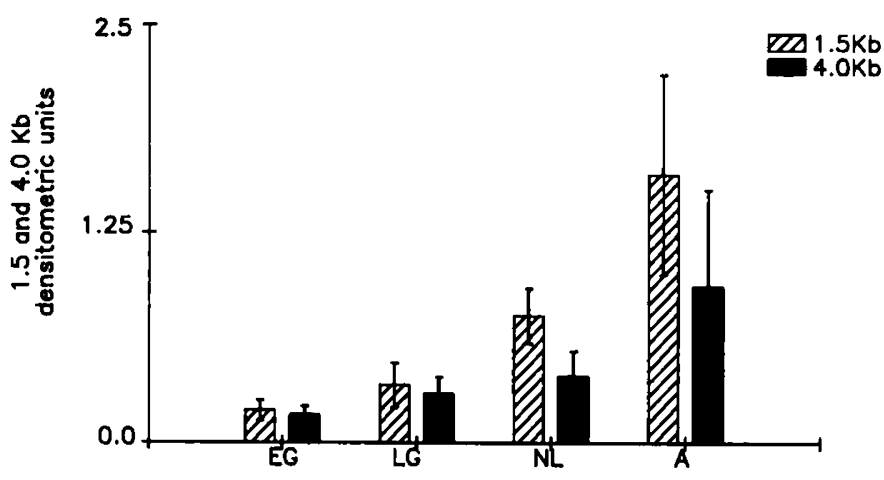

Fig. 5. Quantitative analysis of the $1.5-\mathrm{kb}$ and $4.0-\mathrm{kb}$ mRNA species. Both transcripts increase with age $(p<0.0001$ and $p<0.001$, respectively). In newborn lambs and adult sheep the ratios between 1.5 and 4.0 $\mathrm{kb}$ transcript are higher than those observed in fetuses $(p<0.005)$.

increased expression of MnSOD transcripts is associated with an increase in MnSOD activity. The mRNA levels strongly correlate with enzyme activity. These findings suggest that in the ovine kidney cortex the expression of MnSOD is developmentally regulated and that from fetus to adulthood the control of steadystate levels of MnSOD activity is largely dependent on the regulation of MnSOD mRNA levels. A similar mechanism of pretranslational control has been indicated for the CuZnSOD and for many other enzymatic activities (5- $\alpha$-reductase, sucrose isomaltose, amylase, argininosuccinatelyase, catalase, and lactate-phlorizin hydrolase) during development (17-21).

The newborn tissues are exposed to the damaging effect of free oxygen radicals, due to the significant rise in $\mathrm{PO}_{2}$ occurring at birth. Oxidant-mediated injury has been suggested as an important mechanism of renal failure in postischemic reperfusion and tubular necrosis $(2,22)$. In vitro studies have shown that increased levels of MnSOD activity in cultured cells significantly improved cell survival after exposure to high concentrations of $\mathrm{O}_{2}(23,24)$. Thus, the increase in expression of MnSOD observed as gestation progresses may confer to the kidney cortex of mature fetuses increased protection against free oxygen radicals and may be important for the survival of the fetus in the extrauterine environment. At present, factors involved in the developmental increase in MnSOD activity in the kidney are unknown. The observed increase in the perinatal period is temporarily correlated with significant hormonal changes such as the increase in plasma cortisol level. In the lung glucocorticoid hormones increase antioxidant activity along with the increase in the surfactant (25). It is possible that similar factors are acting on the MnSOD expression in the kidney. However, the progressive increase in MnSOD expression observed from newborn to adulthood sug- 
gests that in the extrauterine environment other factors beside hormonal may be important.

MnSOD mRNA in the ovine kidney is represented by two transcripts of 1.5 and $4.0 \mathrm{~kb}$, respectively. Transcripts of the same size have been observed in ovine lung tissue (G. M. R. Carbone and J. C. Rose, unpublished data). Multiple transcripts for the MnSOD have been observed in human and several animal species including rats, mice, cows, and pigs (26). It has been indicated that the sequences at the $3^{\prime}$-untranslated region account for the differences in transcript size (1). In the rat all the transcripts are fully processed (27); however, it is still not known whether they are all efficiently translated to protein. The 3'untranslated region could be biologically active in regulating the expression of MnSOD gene (1).

Our data have shown that both mRNA species increase in the kidney from fetal life to adulthood; however, whereas during fetal life the relative abundance of each transcript is similar, in the newborn and adult the $1.5-\mathrm{kb}$ transcript is approximately 2 times more abundant than the larger $4.0-\mathrm{kb}$ transcript. These findings indicate that there are age-related differences in the regulation of the two mRNA species. The variation in transcript abundance may result from differences in production or stability of each mRNA. The biological significance of the increase in the abundance of one transcript over the other is not clear at present. Our data indicate that in basal conditions both transcripts may be translated to protein because the enzyme activity is well correlated with the combination of both mRNA species and with each individual transcript. However, it is possible that with stimulation the release of active enzyme is achieved primarily by translation of the smaller transcript (28). If this is the case newborns and adult animals would have greater ability to mount an antioxidant response than fetuses. Further studies are necessary to verify this hypothesis.

Acknowledgment. The authors thank Dr. J. W. Strandhoy for his helpful counsel.

\section{REFERENCES}

1. Touati D 1988 Molecular genetics of superoxide dismutases. Free Radic Biol Med 5:393-402

2. Hayashibe H, Asayama K, Kazushige D, Kiyohiko K 1990 Prenatal development of antioxidant enzymes in rat lung, kidney and heart: marked increase in immunoreactive superoxide dismutase, glutathione peroxidase and catalase in the kidney. Pediatr Res 27:472-475

3. Ward PA, Warren JS, Johnson KJ 1988 Oxygen radicals, inflammation and tissue injury. Free Radic Biol Med 5:403-408

4. Frank L, Groseclose EE 1984 Preparation for birth into an $\mathrm{O}_{2}$-rich environment: the antioxidant enzymes in the developing rabbit lung. Pediatr Res 18:240-243

5. Frank L, Sosenko IRS 1987 Prenatal development of lung antioxidant enzymes in four species. J Pediatr 110:106-110

6. Waltgher FJ, Wade AB, Warburton D, Forman HJ 1991 Ontogeny of antioxidant enzymes in the fetal lamb lung. Exp Lung Res 17:39-45
7. Vlessis AA, Mela-Riker L 1989 Perinatal development of heart, kidney and liver mitochondrial antioxidant defense. Pediatr Res 26:220-226

8. Oberley TD, Oberley LW, Slattery AF, Lauchner LJ, Elwell JH 1990 Immunohistochemical localization of antioxidant enzymes in adult syrian hamster tissues and during kidney development. Am J Pathol 137:199-214

9. Bradford MM 1976 A rapid and sensitive method for quantitation of microgram quantities of protein utilizing the principle of protein-dye binding. Anal Biochem 72:248-254

10. Oberley LW, St Clair DK, Autor AP, Oberley TD 1987 Increase in manganese superoxide dismutase in the mouse heart after $\mathrm{x}$-irradiation. Arch Biochem Biophys 254:69-80

11. Chomczynski P, Scaahi N 1987 Single step method of RNA isolation by acid guanidium thiocyanate-phenol chloroform extraction. Anal Biochem 162:156-159

12. Church GM, Gilbert W 1984 Genomic sequencing. Proc Natl Acad Sci USA 81:1991-1995

13. St Clair DK, Holland JC 1991 Complementary DNA encoding human colon cancer manganese superoxide dismutase and the expression of its gene in human cells. Cancer Res 51:939-943

14. Feinberg AP, Vogelstein B 1983 A technique for radiolabeling DNA restriction endonuclease fragments to high specific activity. Anal Biochem 132:6-13

15. Carbone GMR, Sheikh AU, Rogers S, Rose JC 1993 Developmental changes in renin gene expression in ovine kidney cortex. Am J Physiol 264:R591R596

16. Borgstahl GEO, Parge HE, Hyckey MJ, Beyer WF, Hallewell RA, Tainer JA 1992 The structure of human mitochondrial manganese superoxide dismutase reveals a novel tetrameric interface of two 4-helix bundles. Cell 71:107118

17. Buller HA, Kothe MJ, Goldman DA, Grubman SA, Sasak WV, Matsudaira PT, Montgomery RK, Grand RJ 1990 Coordinate expression of lacasephlorizin hydrolase mRNA and enzyme levels in rat intestine during development. J Biol Chem 265:6978-6983

18. Husson AS, Renouf A, Fairand C, Buquet M, Benamar R, Vaillant R 1990 Expression of argininosuccinate lyase mRNA in foetal hepatocytes: regulation by glucocorticoids and insulin. Eur J Biochem 192:677-681

19. Lee PC, Kratz B, Kim O, Moshier J, Lin CH 1990 Expression of the amylase gene in the rat exocrine pancreas during postnatal development: effect of dexamethasone. Biochem Biophys Acta 1049:244-248

20. Leeper LL, Henning SJ 1990 Development and tissue distribution of sucraseisomaltase mRNA in rats. Am J Physiol 258:G52-G58

21. Lephart ET, Andersson S, Simpson ER 1990 Expression of neural 5 alphareductase messenger ribonucleic acid: comparison to 5 alpha-reductase activity during prenatal development in the rat. Endocrinology 127:1121-1128

22. Flaherty JT, Weisfeldt ML 1988 Reperfusion injury. Free Radic Biol Med 5:409-419

23. Krall J, Bagley AC, Mullenbach GT, Hallewell RA, Lynch RE 1988 Superoxide mediates the toxicity of paraquat for cultured mammalian cells. J Biol Chem 263:1910-1914

24. St Clair DK, Oberley TD, Ye-Shih H 1991 Overproduction of human Mnsuperoxide dismutase modulates paraquat-mediated toxicity in mammalian cells. FEBS Lett 293:199-203

25. Frank L. Lewis PL, Sosenko IRS 1985 Dexamethasone stimulation of fetal rat lung antioxidant enzyme activity in parallel with surfactant stimulation. Pediatrics 75:569-574

26. Visner GA, Block ER, Burr IM, Nick HS 1991 Regulation of manganese superoxide dismutase in porcine pulmonary artery endothelial cells. Am J Physiol 261:L444-L449

27. Hurt J, Hsu J-L, Dougall WC, Visher GA, Burr IM, Wiek HS 1992 Multiple mRNA species generated by alternate polyadenylation site from the rat manganese superoxide dismutase. Nucleic Acids Res 20:2185-2190

28. St Clair DK, Oberley LW 1991 Manganese superoxide dismutase expression in human cancer cells: a possible role of mRNA processing. Free Rad Res Comm 12(Pt. 2):771-778 